\title{
IfIISGUC.ORG
}

"İȘ, GÜC̣" ENDÜSTRi ilLișKiLERI VE INSAN KAYNAKLARI DERGISi

"IS, GUC" INDUSTRIAL RELATIONS AND HUMAN RESOURCES JOURNAL

\section{Kişiliğin Girişimcilik Niyeti Üzerine Etkisi: Üniversiteli Gençler Üzerine Bir Uygulama}

\author{
The Effect of Personality on Entrepreneurship \\ Intention: An Application on University Youth
}

\author{
Oğuz Başol
}

Uludağ Üniversitesi, Sosyal Bilimler Enstitüsü

Arş. Gör. Salih Dursun

Uludağ Üniversitesi, Sosyal Bilimler Enstitüsü

Prof. Dr. Serpil Aytaç

Uludağ Üniversitesi, İIBF, ÇEEİ Bölümü

Ekim/October 2011, Cilt/Vol: 13, Sayı/Num:4, Page: 7-22

ISSN: 1303-2860, DOI: 10.4026/1303-2860.2011.186.x

Makalenin on-line kopyasına erişmek için:

http://www.isguc.org/?p=article\&id=473\&vol=13\&num=4\&year=2011

To reach the on-line copy of article:

http://www.isguc.org/?p=article\&id=473\&vol=13\&num $=4 \& y e a r=2011$

Makale İçin İletişim/Correspondence to: 
(C) 2000- 2011

"İşGüç" Endüstri İlişkileri ve İnsan Kaynakları Dergisi

"İşGüç" Industrial Relations and Human Resources Journal

Ekim/October 2011, Cilt/Vol: 13, Say1/Num: 4

ISSN: 1303-2860, DOI: 10.4026/1303-2860.2011.186.x

Editör/Editor-in-Chief

Aşkın Keser (Uludağ University)

Editör Yardımcıları/Co-Editors

K.Ahmet Sevimli (Uludă̆ University)

Gözde Yllmaz (Marmara University)

Uygulama/Design

Yusuf Budak (Kocaeli Universtiy)

\author{
Yayın Kurulu / Publishing Committee \\ Dr.Zerrin Firat (Uludă̆ University) \\ Doç.Dr.Aşkın Keser (Uludağ University) \\ Prof.Dr.Ahmet Selamoğlu (Kocaeli University) \\ Yrd.Doç.Dr.Ahmet Sevimli (Uludağ University) \\ Yrd.Doç.Dr.Abdulkadir Şenkal (Kocaeli University) \\ Yrd.Doç.Dr.Gözde Yılmaz (MarmaraUniversity) \\ Dr.Memet Zencirkıran (Uludă̆ University)
}

Uluslararası Danışma Kurulu / International Advisory Board

Prof.Dr.Ronald Burke (York University-Kanada)

Assoc.Prof.Dr.Glenn Dawes (James Cook University-Avustralya)

Prof.Dr.Jan Dul (Erasmus University-Hollanda)

Prof.Dr.Alev Efendioğlu (University of San Francisco-ABD)

Prof.Dr.Adrian Furnham (University College London-İngiltere)

Prof.Dr.Alan Geare (University of Otago- Yeni Zellanda)

Prof.Dr. Ricky Griffin (TAMU-Texas AEM University-ABD)

Assoc. Prof. Dr. Diana Lipinskiene (Kaunos University-Litvanya)

Prof.Dr.George Manning (Northern Kentucky University-ABD)

Prof. Dr. William (L.) Murray (University of San Francisco-ABD)

Prof.Dr.Mustafa Özbilgin (University of East Anglia-UK)

Assoc. Prof. Owen Stanley (James Cook University-Avustralya)

Prof.Dr.Işık Urla Zeytinoğlu (McMaster University-Kanada)

Danışma Kurulu / National Advisory Board

Prof.Dr.Yusuf Alper (Uludağ University)

Prof.Dr.Veysel Bozkurt (Uludağ University)

Prof.Dr.Toker Dereli (Işık University)

Prof.Dr.Nihat Erdoğmuş (Kocaeli University)

Prof.Dr.Ahmet Makal (Ankara University)

Prof.Dr.Ahmet Selamoğlu (Kocaeli University)

Prof.Dr.Nadir Suğur (Anadolu University)

Prof.Dr.Nursel Telman (Maltepe University)

Prof.Dr.Cavide Uyargil (İstanbul University)

Prof.Dr.Engin Yildırım (Sakarya University)

Doç.Dr.Arzu Wasti (Sabancı University)

Dergide yayınlanan yazllardaki görüşler ve bu konudaki sorumluluk yazarlarına aittir.

Yayınlanan eserlerde yer alan tüm içerik kaynak gösterilmeden kullanılamaz.

All the opinions written in articles are under responsibilities of the outhors.

None of the contents published can't be used without being cited. 


\title{
Kişiliğin Girişimcilik Niyeti Üzerine Etkisi: Üniversiteli Gençler Üzerine Bir Uygulama
}

\author{
The Effect of Personality on Entrepreneurship \\ Intention: An Application on University Youth
}

\author{
Oğuz Başol \\ Uludağ Üniversitesi, Sosyal Bilimler Enstitüsü \\ Arş. Gör. Salih Dursun \\ Uludağ Üniversitesi, Sosyal Bilimler Enstitüsü \\ Prof. Dr. Serpil Aytaç \\ Uludağ Üniversitesi, İ̉BF, ÇEEİ Bölümü
}

\begin{abstract}
Özet
Bu çalışmada üniversite öğrencilerinin girişimsel öz-yeterlilik özellikleri ile kişilikleri arasındaki ilişki araştırılmaktadır. Bu amaç doğrultusunda Uludağ Üniversitesi, İktisadi ve İdari Bilimler Fakültesi öğrencileri arasından rassal olarak seçilen 250 öğrenciye, Eysenck Kişilik Anketi, Girişimci Öz Yeterlilik Ölçeği ve bazı sosyo-demografik sorulardan oluşan bir anket uygulanmıştır. Bu çalışma sonucunda, dışa dönüklük kişilik boyutunun; "yeni ürün ve pazar firsatları geliştirmek", "yenilikçi bir çevre oluşturmak", "yatırımcılarla ilişkileri başlatmak", "temel amacı tanımlamak", "beklenmedik zorluklarla baş etmek" ve "temel insan kaynakları geliştirmek" boyutlar ile pozitif yönlü ve anlaml bir iliş̧i içinde olduğu tespit edilmiştir. Ayrıca nörotisizm kişilik boyutunun "yenilikçi bir çevre oluşturmak" ve "yatırımcılarla ilişkileri başlatmak" boyutları ile negatif yönlü ve anlamlı bir ilişkide olduğu bulunmuştur.
\end{abstract}

Anahtar Kelimeler: Kişilik, Girişimcilik niyeti, Girişimsel özyeterlilik, Üniversite gençlĭ̆i, Dışadönüklük

\begin{abstract}
This study aimed to investigate the relationship between personality characteristics and entrepreneurial self-efficacy among university students. The sample was composed of 250 university students who were randomly chosen. In the study we used Eysenck Personality Questionnaire and Entrepreneurial Self-Efficacy Scale. According to the results obtained from the research, it is found that the personality dimension of extraversion has a positive and significant correlation with the dimensions of the Entrepreneurial Self-Efficacy Scale: "developing new product and market opportunities", "building an innovative environment", "initiating investor relationships", defining core purpose", "coping with unexpected challenges" and "developing critical human resources". Otherwise, neuroticism personality dimension has a significant negative correlation with "building an innovative environment" and "initiating investor relationships".
\end{abstract}

Keywords: Personality, Entrepreneurship intention, Entrepreneurial self-efficacy, University youth, extraversion 


\section{GíRiş}

Küreselleşme ile birlikte değişen rekabet koşulları günümüzde birçok ülkenin ekonomik ve sosyal sorunlar yaşamasına neden olmaktadır. Bu sorunların başında ise, yeterli istihdamın yaratılamaması ya da kişilerin kendi girişimlerini hayata geçirememesi gelmektedir. Girişimciliğin istihdam sorununa bir çözüm olabileceği noktasında, Avrupa ülkelerinde yapılan araştırmalar, yaratılan istihdamda girişimciliğin büyük payının olduğunu göstermiștir (TÜSİAD, 2002:40). Örneğin EUROSTAT tarafından yapılan bir araştırmada, 2005 yılında Avrupa Birliği'nde 19,6 milyon girişim işletmesi olduğu, bu işletmelerin 85 milyon civarında istihdam yarattığ1 ve 3 trilyon doların üzerinde bir ekonomik katkı sağladığı sonucuna ulaşılmiştır (Schmiemann, 2008:1). Diğer yandan ABD'de yapılan çalışmalarda da benzer bulgulara rastlanmıştır. Örneğin ABD'de 19651985 dönemi aralığında nüfus 129 milyondan 180 milyona çıkmış ve bu dönemde çalışan sayısı da 71 milyondan 106 milyona yükselmiştir. Bu 20 yıl içinde yaratılan 35 milyon kişilik istihdam artışının 24 milyonu, 1974-1985 yılları arasında kurulan yeni işletmelerden kaynaklanmaktadır (Drucker, 2007:1-2). Ayrıca diğer ülkelerde yapılan ulusal tabanlı araştırmalarda da, girişimciliği destekleyen ülkelerin, işsizlikle mücadelede önemli yol kat ettiği rapor edilmiştir (Sondakh ve Rajah, 2006: 233). Nitekim Türkiye'de de girişimcilerin oluşturduğu ekonomi, üretilen katma değerin \%37,7'sini oluşturmaktadır (OECD, 2005:18)

Modern tanımına bakıldığında girişimci, risk alarak yenilik yapan kişidir. Diğer bir ifade ile girişimci, firsatları takip eden ve onları bulduğunda her tür riski alarak amacını gerçekleştirmeye çalışan kişi olarak tanımlanmaktadır (TÜSİAD, 2002:33). Bir başka tanıma göre ise girişimci, mal veya hizmet üretmek ya da pazarlamak için üretim faktörlerini (doğal kaynaklar, işgücü ve sermaye) bir araya getiren, kar amacı güden ve zarar olasılığını göze alan kişi olarak tanım- lanmaktadır (Sabuncuoğlu ve Tokol, 2009:5). Dolayısıyla girișimcilik, çağımızın yükselen bir değeri durumundadır. Özellikle girişimciliğin bir sonucu olarak kurulan yeni işletmeler, istihdamı arttırma imkânları nedeniyle, günümüzün ekonomik yapısının etkin aktörleri olarak ortaya çıkmaktadırlar. Bu bakımdan dünya ekonomisinde görülen yeniden yapılanma sürecinin ateşleyici unsurunu da, kuşkusuz girişimciler oluşturmaktadır. Yaratıcılıktan yeniliğe, atak olmaktan cesarete, risk almaktan hayalciliğe kadar çeşitli sıfatlarla anılan girişimciler, toplumsal ve iktisadi değişimin motorize gücü olarak karşımıza çıkmaktadırlar (Aytaç ve Ömer, 2007:102).

Girişimciliğin istihdam sorununa çözümü noktasından hareketle birçok ülkede girişimcilik faaliyetleri teşvik edilmektedir. Yasal, kültürel, sosyal ve ekonomik açıdan pek çok faktör girişimcilik üzerinde etkili olmaktadır. Diğer taraftan, girişimcilik konusunda üzerinde önemle durulan faktörden biri de girişimci kişiliktir.

\section{GIRIŞiMCILIK VE KişíLIKK}

Kişiliğin girişimcilikle ilişkisi konusunda birçok araştırmacı hemfikir olmakla beraber, hangi kişilik tipinin girişimcilikte belirleyici olduğu noktasında farklılıklar ortaya çıkabilmektedir. Çalışmanın ilerleyen kısımlarinda ortaya konulduğu üzere bu konuda farklı düşünceler söz konusudur.

Girişimci kişiliği oluşturan başlıca unsurlar incelendiğinde, yapılan birçok çalışma başarılı girişimci karakterinin ana unsurunun yaratıcılık olduğunu önemle vurgulanmaktadır (Lee ve diğ., 2004:881). Schumpeter'in de ifade ettiği gibi girişimci "yıkıcı yaratıcılık" görevini üstlenmiştir. Yaratıcılık girişimcilik ile beraber kullanıld1ğında, fark yaratan fikirleri ve buluşları değerlendirerek, pazara sunmayı ifade eder ve bu şekliyle yenilikçi özelliğe sahip organizasyonlar, kendilerini hızla değişen şartlara uyarlama ve rekabet üstünlügüünü elde etme şansına sahiptirler (İlter, 2008:40-42). 
Fark yaratan fikirleri yeni bir şekilde ileri sürdükten sonra girișimci, yeterli riski üstlenebilmelidir. Başarılı girişimci, risk düzeyini potansiyel kazançlara göre ayarlayabilen ve belirsizlik yönetim kapasitesi yüksek olan bireyler olarak tanımlanmaktadır (Brindley, 2005:146). Benzer şekilde Cantillon'un girişimcilik tanımının bel kemiğini de risk alma davranışı oluşturmaktadır (Carsrud ve Brannback, 2007:7). Genel kanı, risk alma tutumunun, girişimcileri girişimci olmayanlardan ayıran en önemli özellik olduğu yönündedir, hatta bazı yazarlara göre risk alma davranışı, girişimcileri yöneticilerden ayırt eden en önemli özellik olarak vurgulanmaktadır (İlter, 2008:38).

Bir diğer önemli kişilik özelliği ise "özgüven" olarak tanımlanmaktadır. Buna göre özgüven, bireyin kendisiyle ilgili iyi duygular taşıması sonucunda, kendisini iyi hissetmesi, kendisinden memnun olması ve hiçbir olumsuzluğun kendisine zarar vermeyeceğine inanması sonucunda ortaya çıkan hisler olarak tanımlanmaktadır (Cansız 2007: 60). Stratejik düşüncenin öne çıktığ 1 yenidünya düzeninde girişimciler, günlük hayatta faaliyette bulunurken ayn zamanda çevrelerinde meydana gelen değişmelere ayak uydurmak durumundadır. Bu süreç içinde girişimciyi öncü olmaya iten kişilik özelliği özgüvenidir. Böylelikle kendine ve yaptığ işlere güvenen girişimci, risk üstlenir ve yenilikçilik açısından ile fark yaratır (Odabaş1, 2005:25; Oosterbeek ve diğ., 2010:446-447).

Diğer taraftan, liderlik, girişimci kişiliğin önemli bir parçası olarak değerlendirilmektedir. Lider, bireyleri hedeflere yönlendiren ve gruplar arasında iletişimi kurmaya çal1şan kişi olarak tanımlanmaktadır. Kimi yazarlar ise lideri "olumsuz olaylardan bir anlam bulabilme ve en zorlayıc koşullardan ders çıkarabilme yeteneği olan kişi" olarak da tanımlamaktadır (Bennis ve Thomas, 2005:152). İnsanların büyük bir çoğunluğu dürüst, ileri görüşlü, ilham veren ve yetenekli liderlere hayran olur ve böyle liderlerin takipçisi olmak isterler (Kutanis ve Alpaslan,
2007:26). Lider; büyük resmi saptamak, gerçekler, deneyimler ve zekâdan hareketle doğru yargılamayı adil bir şekilde yapmak, yaratıcılık, yenilikçilik ve muhtemel fırsatları görmek, mevcut firsatlardan hareketle mantıklı süreçleri izlemek, yüksek verimlilik ve etkinlik sağlayacak kararlar vermek gibi aşamaları takip etmektedir. Dolayısıyla, bir girişimcide bulunması gereken anahtar özeliklerden biri de liderliktir. Nitekim girişimci, Schumpeter tarafından (Schumpeter'in girişimcilik kavramı üzerinde önemle durduğu unsur yenilikçiliktir) sosyoekonomik gelişmenin yenilikçi lideri olarak tanımlanmaktadır (Tiryaki, 2005:35).

Girişimci kişilik kavramı incelendiğinde daha önce de belirtildiği gibi yenilikçi, risk alabilen, özgüveni yüksek ve liderlik özellikleri öne çıkan bireyler akla gelmektedir. Ancak yalnızca bu özelliklere sahip olmak girişimcinin başarılı olmasını sağlamaya yetmemektedir. Başarılı girişimciyi güdüleyecek kişilik faktörlerinin dişında bir takım unsurlar vardır ve bu unsurlar literatürde yeni fırsatların farkına varma (Baum ve diğ., 2007:3), uygun personel politikası geliştirme (Baum ve diğ., 2007:4; Morrison, 2000:62), risk alabilme, özgüven sahibi olma (Oosterbeek ve diğ., 2010:446), vizyon sahibi olma, yeni ürün ve hizmet geliştirme (Chen ve diğ., 1998:300; Krueger, 2000:5), finansal kaynaklara yakın olma (Taylor ve Newcomer, 2005:24), yenilikçi çevre yaratma (Baum ve diğ., 2007:1) ve beklenmedik zorluklar ile başa çıkma (De Noble ve diğ., 1999) olarak ele alınmaktadır.

Diğer taraftan, baskın kişilik tiplerinin girişimcilik ile ilgisi incelendiğinde ise, dışadönüklük, nörotisizm ve psikotisizm olmak üzere üç kişilik tipinin öne çıktığı görülmektedir (Shane, 2003; Johnston ve diğ., 2010). Dışa dönüklük, sosyalliği ve dürtüselliği temsil etmektedir. İnsanlarla iletişimi seven, girişken ve yalnız olmaktansa insanlarla olmayı tercih eden birey dışadönük olarak tanımlanmıştır (Eysenck, Eysenck 1975). Bu nedenle dişadönük kişilerin girişimci kişiler olması beklenmektedir. Yapılan araştırmalar 
da bunu desteklemektedir. Örneğin Wooten ve diğ. (1999) şu anda girișimci olan ve olmayan bireylerin önceki tutumlarını karş1laştırdıklarında, şimdiki girişimcilerin kendi işlerini kurmadan önce de (şu anda girişimci olmayanlara kiyasla) daha sosyal bireyler olduğu sonucuna ulaşmıştır. Nitekim bu sonuç, dışa dönüklük ile girişimcilik arasında kuvvetli bir bağ olduğuna dikkat çekmektedir. Benzer bir sonuç da Roberts'in (1991) yaptığ1 araştırmadan elde edilmiştir. Buna araştırmadan elde edilen sonuçlara göre, ileri teknoloji üzerine uzmanlaşmış ve şu anda kendi işini kurmuş bireyler, başkaları adına iş yürüten ileri teknoloji uzmanlarından daha dişadönüktür (Shane, 2003: 98).

Nörotisizm ise, duygusal tutarsızlığı veya aşırı tepkiselliği temsil etmektedir. Bu kişilerin kaygılı, depresif, gergin, çekingen, aşırı duygusal ve düşük öz-güvenli olabileceği belirtilmektedir (Eysenck, Eysenck, 1975). Girişimci olmak ise, beraberinde duygusal denge sahibi olmay1 gerektirmektedir. Nitekim girişimcilerde strese karşı tolerans, ağır iş yükü ile baş etme, risk alma, kimi zaman sosyal bask1, finansal zorluklarla baş etme ve kendi işletmelerinin işleyişi ile ilgili sürekli olarak baskı altında olma durumu söz konusudur. Dolayısıyla, nörotisizm kişilik tipine sahip olan kişilerin girişimci olmaları büyük bir dikkat gerektirmektedir (Shane, 2010: 155).

Son olarak psikotisizm ise, soğuk, mesafeli, saldırgan, güvensiz, duygusuz, empati kuramama ve diğer insanlara karşı duyarsızlık gibi daha çok sıra dışı kişilik özelliklerini temsil etmektedir (Eysenck, Eysenck, 1975). Diğer yandan psikotik kişiliğe sahip bireylerin yüksek sanatsal (müzik, resim, yazı) yaratıcılığa sahip oldukları da bilinmektedir. Bu kişiler yaratıcılıklarını toplumdan soyutlanarak gerçekleştirmektedir (Shane, 2010: 146-147). Diğer bir ifade ile bu kişiliğe sahip bireylerin yaratıcılıkları girişimci olmak adına değil, sanatsal yaratıcılık adına gerçekleşmektedir. Girişimci olmak beraberinde yüksek yaratıcılık gerektirse de tek başına yaratıcı olmak ağır iş yükü ile baş etme, risk alma, finansal zorluklarla baș etme gibi değerlerden yoksun olarak başarıya ulaşamamaktadır. Dolayısıyla, bu kişilik tipine sahip olan bireylerin girișimci olmaları yaratıcılıkları ile diğer özelliklerini iyi bir şekilde harmanlamasını gerektirmektedir.

\section{UYGULAMA}

\subsection{Amaç}

Bu çalışmanın amacı üniversite öğrencilerinin girişimci öz-yeterlilik özellikleri ile kişiliklerinin ilişkili olup olmadığ 1 araştırmaktır. Bu amaç doğrultusunda Uludağ Üniversitesi İktisadi ve İdari Bilimler Fakültesinde 2010-2011 güz döneminde eğitim gören birinci, ikinci, üçüncü ve dördüncü sınıf öğrencileri arasından 250 kişi rassal olarak seçilerek anket uygulanmıştır. Elde edilen anketlerden 25'i eksik veri içerdiği için kapsam dişında birakılmış ve analizler 225 kişi üzerinden gerçekleştirilmiştir.

\subsection{Yöntem}

Çalışmada kullanılan anket formu üç bölümden oluşmaktadır:

Kişisel bilgi formu: Anket formunun ilk bölümünde öğrencilere ait yaş, cinsiyet ve sınıf gibi demografik bilgiler yer almaktadır.

Eysenck Kişilik Anketi - Gözden Geçirilmiş Kısaltılmış Formu (EKA-GGK): Eysenck Kişilik Anketi (Eysenck ve Eysenck, 1975) ve aynı anketin kisa formunu (48 madde) (Eysenck ve diğ., 1985) uzun bir ölçek olarak gören Francis ve diğerleri (1992) gözden geçirerek EKA-GGK'yı oluşturmuşlardır. Ölçeğin Türkçe geçerlilik ve güvenilirlik çalışması Karancı ve diğerleri (2007) tarafından yapılmıştır. Anket 24 madde olup kişiliği, dişadönüklük, nörotizm ve psikotizm olmak üzere 3 ana faktörde değerlendirmektedir. Bunun yanı sıra "yalan söyleme" alt ölçeği ile anketin uygulanması esnasındaki yanlılığı engellemek ve geçerliliği ile ilgili kontrol amaçlanmaktadır*. Bu ölçeğe ait

\footnotetext{
* Yalan söyleme alt ölçeği yalnızca kontrol niteliği taşıdığından bu alt ölçeğe ait sonuçlara bu çalışma kapsamında yer verilmemiştir
} 
faktörler incelendiğinde;

- Dışa dönüklük, sosyalliği ve dürtüselliği temsil ederken, bu boyutta yüksek puan alan kişiler, insanlarla iletişimi seven, girişken ve yalnız olmaktansa insanlarla olmayı tercih eden biri olarak tanımlanmıştır (Ör: "Konuşkan bir kişi misiniz? Oldukça canlı bir kişi misiniz?").

- Nörotisizm boyutunun, duygusal tutarlılığa veya aşırı tepkiselliğe işaret etmekte olduğu ve bu boyutta yüksek puan alan bir kişinin kaygılı, depresif, gergin, çekingen, aşırı duygusal ve düşük öz-güveni olabileceği öne sürülmüştür (Ör: "Sinirlerinizden şikâyetçi misiniz? Sıklıkla kendinizi her şeyden bıkmış hisseder misiniz?").

- Psikotisizim boyutu ise soğuk, mesafeli, saldırgan, güvensiz, duygusuz, tuhaf ve empati kuramama, suçluluk ve diğer insanlara karşı duyarsızlık gibi daha çok sıra dışı kişilik özelliklerini ifade etmektedir ("Borçlu olmak sizi endişelendirir mi? Kurallara uymak yerine kendi bildiğiniz yolda gitmeyi mi tercih edersiniz?") (Eysenck, Eysenck 1975).

Her bir faktörün (dışa dönüklük, nörotisizm, psikotisizm ve yalan söyleme) 6 madde ile değerlendirildiği bu ankette kat1lımcidan 24 soruya Evet (1) ve Hayır (0) formatiyla cevap vermeleri istenmekte, her bir kişilik özelliği için alınabilecek puan 0 ile 6 arasında değişmektedir (Karancı ve diğ., 2007:3).

Girişimci Öz Yeterlilik Ölçeğgi: De Noble ve diğerleri (1999) ve Kickul ve D'Intino (2005) tarafından geliştirilen, 6 boyut içeren ve 35 maddeden (Türkçe geçerlilik çalışmasında 7. ve 9. soruların hiçbir faktöre ait olmadığ 1 sonucuna ulaşılmış ve hesaplamalar 33 soru üzerinden yapılmıştır) oluşan ve Türkçe geçerliliği Naktiyok ve diğerleri (2010) tarafından yapılan bir ölçektir. Girişimci öz yeterlilik ölçeği boyutları ise şu şekildedir (De Noble ve diğ., 1999):
- Temel amacı tanımlamak: İşletme için vizyon ve misyon belirleme bunun yanı sira yatırımcilar ve nitelikli personel ile iletişime geçebilme ile ilgili yeteneklerdir (Ör: "Diğerlerine işletmenin vizyonunu ve değerlerini benimsemeleri için ilham verebilirim").

- Beklenmedik zorluklarla baş etmek: Risk ve belirsizlik içeren durumlarla başa çıkabilme ile ilgili yeteneklerdir. Bu yeteneğe sahip girişimciler, girişimlerde kriz durumlarında ortaya çıkan gerginliği idare edebilmektedir (Ör: "Sürekli stres, baskı ve çatışma altında üretken biçimde çalışabilirim").

- Yenilikçi bir çeore oluşturmak: Çevredeki kişileri cesaretlendirme kapasitesi ile ilgili yeteneklerdir. Bu yeteneğe sahip olan bireylerin, kendi kararlarının sorumluluklarını taşıyabilecek ve çevrelerindeki kişileri yaratıcı kararlar almaya teşvik edecek kapasiteye sahip oldukları kabul edilmektedir (Ör: "Interaktif bir iş ortamının oluşumunu teşvik edebilirim") (Chen ve diğ., 1998).

- Yeni ürün ve pazar firsatları geliştirmek: Piyasadaki fırsatları fark edebilme ile ilgili yeteneklerdir. Bu yeteneğin yüksek olduğu bireyler sürekli olarak yeni ve başarılı olabilme ihtimaline sahip girişimlerin farkındadır ("Ör: İş fırsatlarının avantajlarından yararlanmak için çabucak harekete geçebilirim") (Krueger, 2000:16).

- Yatırımcılarla ilişki başlatmak: İşletmenin kuruluş aşamasında gerekli olan fon kaynağının temin edilebilmesi ile ilgili yeteneklerdir. Bu yetenek vizyon sahibi girişimcinin ekonomik hayatına devam edebilmesi için ulaşması gereken kaynakları temsil etmektedir (Ör: "Sermaye kaynaklarıyla bağlantısı olan kilit konumdaki kişilerle ilişkiler kurabilirim").

- Temel insan kaynaklarm belirlemek: Uygun insan kaynakları politikası geliştirmek ve nitelikli personelin istihdam edilebilmesi ile ilgili yeteneklerdir. 
Bu yeteneğe sahip girişimciler herhangi bir görev için uygun yeteneklere sahip kişilerin istihdamını sağlayacak vizyona sahiptir (Ör: "Yönetim takımları belirleyebilir ve oluşturabilirim").

Araştırma verileri bilgisayarda SPSS 13.0 programı ile analiz edilmiştir. Veriler değerlendirilmeden önce, "Kolmogorov Smirnov Testi" ile normal dağılıma uygunluğu araştırılmıştır. Kișilik ölçeğiyle ilgili normal dağ1lım analizi sonuçları incelendiğinde Nörotisizm (K-S: 1,947, p<0,05), Dişa dönüklük (K-S: 3,247, p<0,05) ve Psikotisizm (K-S: 2,985, p<0,05) değişkenlerin normal dağılmadığı belirlenmiştir. Dolayısıyla bu üç kişilik boyutuna ilişkin yapılacak analizlerde parametrik olmayan testler tercih edilmiştir. Girişimci öz yeterlilik ölçeği boyutlarının normal dağ 1 lım analizi incelendiğinde ise; yeni ürün ve pazar fırsatları geliştirmek (KS: 2,055, p<0,05), yenilikçi bir çevre oluşturmak (K-S: 2,017, p<0,05), yatırımcilarla ilişkileri başlatmak (K-S: 2,483, p<0,05), temel amacı tanımlamak (K-S: 1,878, $\mathrm{p}<0,05)$ boyutu ile temel insan kaynakları geliştirmek (K-S: 2,436, p<0,05) boyutlarının normal dağılıma uymadığı, yalnızca beklenmedik zorluklarla baş etme (K-S: $1,201, \mathrm{p}>0,05)$ boyutunun normal dağılıma uyduğu belirlenmiştir. Dolayısıyla beklenmedik zorluklarla baş etme boyutu ile ilgili analizlerde parametrik olan testler kullanılırken, diğer boyutlarda parametrik olmayan analizler kullanılmıştır.

\subsection{Bulgular}

Araştırmanın örneklemini oluşturan öğrencilerin \%34,2'sini birinci sınıf öğrencileri, $\% 15,1$ 'ini ikinci sınıf öğrencileri, \%12,4'ünü üçüncü sınıf öğrencileri ve \%38,2'sini ise dördüncü sınıf öğrencileri oluşturmaktadır. Çalışmaya katılan öğrencilerin \%31,6's1 erkek öğrencilerden, \%68,4'ü ise kız öğrencilerden oluşmaktadır (Tablo 1). Öğrencilerin yaş ortalamas $21 \pm 1,65$ olup, minimum yaş 18 , maksimum yaş ise $27^{\prime}$ dir.

Tablo 2' de Eysenck kişilik ölçeğinin her bir boyuta ait madde sayısı, elde edilen or-

\section{Tablo 1}

Öğrencilerin Sosyo-Demografik ve Diğer Özelliklerinin Demografik Analizi

\begin{tabular}{|c|c|c|}
\hline Cinsiyet & $\mathbf{N}$ & $\mathbf{\%}$ \\
\hline Kiz & 154 & 68,4 \\
\hline Erkek & 71 & 31,6 \\
\hline Sinıf & $\mathbf{N}$ & $\mathbf{\%}$ \\
\hline I.sinif & 77 & 34,2 \\
II. sinıf & 34 & 15,1 \\
III. sinif & 28 & 12,4 \\
IV. sinıf & 86 & 38,2 \\
\hline
\end{tabular}

talamalar ve standart sapma değerleri sunulmuştur. Buna göre; nörotisizm alt ölçeğinin ortalaması: $3,20 \pm 1,85$; dişa dönüklük alt ölçeğinin ortalamasi: $3,86 \pm 1,93$ ve psikotisizm alt ölçeğinin ortalaması: $1,47 \pm 1,03$ olarak hesaplanmıştır.

\section{Tablo 2}

Eysenck Kişilik Anketi Boyutlarına İlişkin Değerler

\begin{tabular}{|c|c|c|c|}
\hline Boyutlar & $\begin{array}{c}\text { Madde } \\
\text { Sayısı }\end{array}$ & Ort. & $\begin{array}{c}\text { S.Sapm } \\
\text { a }\end{array}$ \\
\hline Nörotisizm & 6 & 3,20 & 1,85 \\
\hline Dışa Dönüklük & 6 & 3,86 & 1,93 \\
\hline Psikotisizm & 6 & 1,47 & 1,03 \\
\hline
\end{tabular}

Tablo 3'de Eysenck kişilik anketinin boyutlarına ilişkin bu çalışma kapsamında elde edilen güvenilirlikleri, Karancı ve diğerleri (2007) ve Francis ve diğerleri (1992) çalışmalarından elde edilen güvenilirlikler karşılaştırılmalı şekilde sunulmuştur.

Ölçekte yer alan maddelerin içsel tutarlılığının ölçülmesinde kullanılan Cronbach Alpha değerlerine bakıldığında, nörotisizm için 0,70 , dişa dönüklük için 0,78 ve psikotizm için 0,32 olarak bulunmuştur. Bu değerlerden özellikle psikotisizm boyutunun hem ülkemizde hem de diğer ülkelerde yapılan çalışmalarda sosyal bilimler alanında 
Tablo 3

Eysenck Kişilik Anketi Boyutlarına İlişkin Güvenirlik Değerleri Karşılaştırılması

\begin{tabular}{|c|c|c|c|c|c|c|}
\hline \multirow{2}{*}{ Boyutlar } & \multirow{2}{*}{ C.Alpha** } & \multirow{2}{*}{ C.Alpha* } & \multicolumn{5}{|c|}{ C.Alpha* } \\
\cline { 4 - 7 } & & & Ingiltere & Kanada & ABD & Avustralya \\
\hline Nörotisizm & 0,70 & 0,65 & 0,79 & 0,80 & 0,81 & 0,83 \\
\hline Dişa Dönüklük & 0,78 & 0,78 & 0,78 & 0,83 & 0,85 & 0,87 \\
\hline Psikotisizm & 0,32 & 0,42 & 0,51 & 0,41 & 0,31 & 0,51 \\
\hline
\end{tabular}

* Karancı N, G. Dirik, O. Yorulmaz, Eysenck Kişilik Anketi - Gözden Geçirilmiş Kısaltılmış Formu'nun Türkiye'de Geçerlilik ve Güvenilirlik Çalışması, Türk Psikiyatri Dergisi, 2007; 18(3), s.2-5.

** Bu çalışma kapsamında elde edilmiş C.Alpha değerleridir.

\section{Tablo 4}

Girişimci Öz Yeterlilik Ölçeği Güvenirlik Analizi Sonuçları

\begin{tabular}{|l|c|c|c|c|c|c|}
\hline \multicolumn{1}{|c|}{ Boyutlar } & $\begin{array}{c}\text { Madde } \\
\text { Sayı1s }\end{array}$ & Ort. & S.Sapma & C.Alpha & $\begin{array}{c}\text { Türkiye* } \\
\text { (n:245) }\end{array}$ & $\begin{array}{c}\text { ABD } \\
\text { (n:204) }\end{array}$ \\
\hline $\begin{array}{l}\text { Yeni ürün ve pazar fırsatları } \\
\text { geliştirmek }\end{array}$ & 8 & 3,68 & 0,65 & 0,85 & 0,67 & 0,71 \\
\hline Yenilikçi bir çevre oluşturmak & 5 & 3,76 & 0,76 & 0,80 & 0,82 & 0,76 \\
\hline Yatırımcılarla ilişkileri başlatmak & 3 & 3,69 & 0,78 & 0,77 & 0,85 & 0,75 \\
\hline Temel amacı tanımlamak & 6 & 3,79 & 0,70 & 0,85 & 0,84 & 0,78 \\
\hline $\begin{array}{l}\text { Beklenmedik zorluklarla baş } \\
\text { etmek }\end{array}$ & 6 & 3,12 & 0,57 & 0,60 & 0,90 & 0,82 \\
\hline $\begin{array}{l}\text { Temel insan kaynaklarını } \\
\text { geliştirmek }\end{array}$ & 5 & 3,79 & 0,67 & 0,80 & 0,93 & 0,83 \\
\hline
\end{tabular}

* Naktiyok, A., Karabey, C.N, Güllüce, A.Ç., 2010, Entrepreneurial Self-Efficacy and Entrepreneurial Intention: the Turkish Case, International Entrepreneurship and Management Journal, 6(4), s.429

kabul edilen güvenilirlik derecesinden son derece düşük olduğu görülmektedir.

Tablo 4 ise, girişimci öz yeterlilik ölçeğiyle ilgili güvenirlik analizi sonuçlarını, Türkiye ve diğer ülkelerde yapılan araştırmalardan elde edilen sonuçlarla karşılaştırmalı olarak göstermektedir.

Tablo 5'te girişimci öz-yeterlilik ölçeğinin boyutları görülmektedir. Tüm soruları içeren girişimci öz yeterlilik ölçeği incelendiğinde ise, Cronbach Alfa değerinin 0,93 olduğu tespit edilmiştir.
Tablo 5'te cinsiyete göre girişimci öz yeterlilik ölçeğinin boyutlarının detayları yer almaktadır. Yeni ürün ve pazar fırsatları geliştirme, yenilikçi bir çevre oluşturma, temel amacı tanımlama faktörlerinde kız ögrrencilerin puanları daha yüksektir. Yatırımcılarla ilişki geliştirme, beklenmedik zorluklarla başa çıma ve temel insan kaynakları geliştirme faktörlerinde ise erkek öğrencileri puanları daha yüksektir. Ancak, cinsiyet göre bakıldığında istatistiksel olarak anlamlı farklılık yalnızca beklenmedik zorluklarla baş etme boyutunda ortaya çıkmaktadır. Buna 
Tablo 5

Girişimci ÖzYeterlilik Ölçeği Boyutlarının Cinsiyete Göre Farklılıkların İncelenmesi

\begin{tabular}{|c|c|c|c|c|c|c|}
\hline Boyutlar & Kiz & Erkek & Test Tipi & $\begin{array}{c}\text { Test } \\
\text { Değeri }\end{array}$ & P Değeri & $\begin{array}{l}\text { Ortalama } \\
\text { Farklılık } \\
\end{array}$ \\
\hline $\begin{array}{l}\text { Yeni ürün ve pazar } \\
\text { fırsatları geliştirmek }\end{array}$ & $3,71 \pm 0,60$ & $3,61 \pm 0,75$ & MW-U* & 5163,0 & 0,37 & 0,10 \\
\hline $\begin{array}{l}\text { Yenilikçi bir çevre } \\
\text { oluşturmak }\end{array}$ & $3,79 \pm 0,73$ & $3,70 \pm 0,82$ & MW-U & 5236,0 & 0,58 & 0,10 \\
\hline $\begin{array}{l}\text { Yatırımcılarla ilişkileri } \\
\text { başlatmak }\end{array}$ & $3,68 \pm 0,70$ & $3,72 \pm 0,78$ & MW-U & 4962,5 & 0,22 & 0,04 \\
\hline Temel amacı tanımlamak & $3,83 \pm 0,65$ & $3,72 \pm 0,78$ & MW-U & 5139,0 & 0,45 & 0,10 \\
\hline $\begin{array}{l}\text { Beklenmedik zorluklarla } \\
\text { baş etmek }\end{array}$ & $3,05 \pm 0,54$ & $3,28 \pm 0,61$ & $t^{* *}$ & $-2,721$ & 0,01 & 0,23 \\
\hline $\begin{array}{l}\text { Temel insan kaynaklarını } \\
\text { geliştirmek }\end{array}$ & $3,78 \pm 0,61$ & $3,82 \pm 0,79$ & MW-U & 4969,0 & 0,29 & 0,04 \\
\hline $\begin{array}{l}\text { Girişimci öz yeterlik } \\
\text { (tüm ölçek) }\end{array}$ & $3,63 \pm 0,47$ & $3,62 \pm 0,64$ & MW-U & 5214,5 & 0,58 & 0,01 \\
\hline
\end{tabular}

*Mann Whitney U Testi

**Independent Sample t Test

göre erkek öğrencilerin beklenmedik zorluklarla baş etme yetenekleri kız öğrencilerden daha yüksektir (t: $-2,721, \mathrm{p}<0,05)$. Genel olarak ölçeğin tümüne bakıldığında ise k1z ve erkek ögrrenciler arasında bir farklılık görülmemektedir.

\section{Tablo 6}

Eysenck Kişilik Anketi ve Girişimci Öz Yeterlilik Ölçeği Boyutları Arasındaki Korelasyonlar

\begin{tabular}{|l|c|c|c|c|c|c|c|c|}
\hline Nörotisizm (1) & 1 & 2 & 3 & 4 & 5 & 6 & 7 & 8 \\
\hline Dişa Dönüklük (2) &,$- 254^{* *}$ & 1 & & & & & & \\
\hline Psikotisizm (3) &, 105 &, $206^{* *}$ & 1 & & & & & \\
\hline $\begin{array}{l}\text { Yeni ürün ve pazar fırsatları } \\
\text { geliştirmek (4) }\end{array}$ &,- 120 &, $229^{* *}$ &, 098 & 1 & & & & \\
\hline Yenilikçi bir çevre oluşturmak (5) &,$- 143^{*}$ &, $190^{* *}$ &,- 069 &, $628^{* *}$ & 1 & & & \\
\hline Yatırımcılarla ilişkileri başlatmak (6) &,$- 136^{*}$ &, $263^{* *}$ &, 061 &, $597^{* *}$ &, $569^{* *}$ & 1 & & \\
\hline Temel amacı tanımlamak (7) &,- 051 &, $179^{* *}$ &, 122 &, $729^{* *}$ &, $647^{* *}$ &, $658^{* *}$ & 1 & \\
\hline $\begin{array}{l}\text { Beklenmedik zorluklarla baş etmek } \\
(8)\end{array}$ &,- 078 &, $237^{* *}$ &, 066 &, $358^{* *}$ &, $213^{* *}$ &, $309^{* *}$ &, $283^{*}$ & 1 \\
\hline $\begin{array}{l}\text { Temel insan kaynaklarını } \\
\text { geliştirmek (9) }\end{array}$ &,- 045 &, $175^{* *}$ &, 045 &, $694^{* *}$ &, $664^{* *}$ &, $565^{* *}$ &, $689^{* *}$ &, $359^{* *}$ \\
\hline
\end{tabular}

${ }^{*} \mathrm{p}<0,05 ;{ }^{* *} \mathrm{p}<0,01$ 
Tablo 6, iki ölçeğin boyutları arasındaki korelasyonları göstermektedir. Buna göre, dışa dönük kişilik ile yeni ürün ve pazar fırsatları geliştirmek ( $r: 0,229, p<0,01)$, yenilikçi bir çevre oluşturmak ( $\mathrm{r}: 0,190, \mathrm{p}<0,01)$, yat1rımcılarla ilişki başlatmak ( $\mathrm{r}: 0,263, \mathrm{p}<0,01)$, temel amaci tanımlamak ( $\mathrm{r}: 0,179, \mathrm{p}<0,01)$, beklenmedik zorluklarla baş etmek (r:0,237, $\mathrm{p}<0,01)$ ve temel insan kaynakları geliştirmek ( $\mathrm{r}: 0,175, \mathrm{p}<0,01)$ değişkenleri arasında pozitif yönlü ve anlamlı bir ilişki vardır. Buna göre dışa dönük kişiliğe sahip olan kişilerin daha başarılı bir girişimci olacağ 1 söylenebilmektedir. Diğer yandan Nörotisizm kişilik tipi ile yenilikçi, bir çevre oluşturmak ( $\mathrm{r}:-0,143, \mathrm{p}<0,05)$ ve yatırımcılarla ilişkileri başlatmak (r:-0,136, p<0,05) arasında negatif yönlü ve anlamlı bir ilişki vardır. Diğer taraftan psikotizm kişilik boyutuyla girişimci öz yeterlilik boyutları arasında herhangi bir anlamlı ilişki tespit edilememiştir.

Tablo 7'de kişilik faktörlerinin girişimci öz yeterlik üzerine etkilerini görmek amacıyla çoklu doğrusal regresyon analizi yapılmıştır. Analizde bağımlı değişken; girişimci öz yeterliliği iken, bağımsız değişkenler kişilik faktörleri olan; dişadönüklük, nörotisizm ve psikotisizmdir. Oluşturulan modelin determinasyon katsayıs $\% 7,4$ ve düzeltilmiş determinasyon katsayısı \%6,1 olarak hesaplanmıştır. Kurulan regresyon modeli (F: 5,877, p<0,01) anlamlı bulunmuştur. Bağımsız değişkenler incelendiğinde ise girişimci öz yeterliliğini etkilen tek değişkenin dişa dönük kişilik tipi (t: 3,528, $\mathrm{p}<0,01)$ olduğu sonucuna varılmaktadır. Modelde yer alan diğer değişkenlerin ise, girişimci öz yeterlilik üzerine etkisi anlamlı bulunamamiştır.

\subsection{Tartışma}

$\mathrm{Bu}$ çalışmada, üniversite öğrencilerinin girişimci öz-yeterlilik özellikleri ile kişiliklerinin ilişkili olup olmadığ incelenmeye çal1şılmıştır. Girişimci öz yeterliliğin cinsiyete göre yapılan karşılaştırmalarında beklenmedik zorluklarla baş etmek boyutu dişındaki diğer boyutlarda anlamlı bir farklılık tespit edilememiştir. Erkek öğrencilerin beklenmedik zorluklarla baş etme yetenekleri kız öğrencilerden anlamlı bir şekilde daha yüksek bulunmuştur. Diğer girişimcilik boyutlarında ise anlamlı bir farklılık tespit edilememiştir. Girişimcilik ve cinsiyet ile ilgili literatüre baktığımızda farklı bulguların elde edildiği görülmektedir. Bymes ve diğerleri (1999) 150 ayrı girişimcilik araştırmasını incelediği bir meta-analiz çalışmasının sonuçlarına göre girişimci erkek öğrencilerin risk alma düzeyleri, kadın girişimcilerin risk alma düzeylerinden daha yüksek bulunmuştur. Avşar (2007) çalışmasında, erkek öğrencilerin risk alma eğilimini kız öğrenci-

Tablo 7

Regresyon Analizi Sonuçları

\begin{tabular}{|c|c|c|c|c|c|c|}
\hline \multirow[b]{2}{*}{$\begin{array}{c}\text { Bağımlı } \\
\text { Değişken }\end{array}$} & \multirow[b]{2}{*}{ Değişkenler } & \multicolumn{2}{|c|}{$\begin{array}{c}\text { Standardize } \\
\text { Edilmemiş } \\
\text { Katsayılar } \\
\end{array}$} & \multirow{2}{*}{$\begin{array}{c}\begin{array}{c}\text { Standardize } \\
\text { Edilmiş } \\
\text { Katsayılar }\end{array} \\
\text { B }\end{array}$} & \multirow[t]{2}{*}{ t Testi } & \multirow[t]{2}{*}{$F$ testi } \\
\hline & & B & St.Hata & & & \\
\hline $\begin{array}{c}\text { Girişimci } \\
\text { Öz Yeterlik }\end{array}$ & $\begin{array}{c}\text { Sabit } \\
\text { Dişadönüklük } \\
\text { Nörotisizm } \\
\text { Psikotisizm }\end{array}$ & $\begin{array}{l}3,406 \\
0,067 \\
-0,018 \\
0,015\end{array}$ & $\begin{array}{l}0,113 \\
0,019 \\
0,020 \\
0,033\end{array}$ & $\begin{array}{c}0,243 \\
-0,061 \\
0,029\end{array}$ & $\begin{array}{c}30,012^{* *} \\
3,528^{* *} \\
-0,901 \\
0,433\end{array}$ & $5,877^{* *}$ \\
\hline R: 0,272 & \multicolumn{2}{|c|}{$R^{2}: 0,074$} & \multicolumn{2}{|c|}{ Düzeltilmiş $R^{2}: 0,061$} & & \\
\hline
\end{tabular}

${ }^{*} \mathrm{p}<0,05 ;{ }^{* *} \mathrm{p}<0,01$ 
lerden yüksek bulunmuştur.

Girişimci öz yeterlilik alt boyutları (yeni ürün ve pazar fırsatları geliştirmek, yenilikçi bir çevre oluşturmak, yatırımcılarla ilişkileri başlatmak, temel amacı tanımlamak, beklenmedik zorluklarla baş etmek, temel insan kaynaklarını geliştirmek) bir anlamda kişinin girişimci olma niyetini ölçebilir niteliktedir. $\mathrm{Bu}$ çalışma kapsamında yalnızca beklenmedik zorluklarla baş etmek boyutunda cinsiyet bağlamında bir farklılık çıkmış olsa da, genel olarak kız ve erkek öğrencilerin girișimci olma niyetleri arasında bir farklılık olmadığı sonucuna ulaşılmiştır. Özden ve diğerleri (2008) çalışmalarında erkek öğrencilerin girişimcilik eğilimlerini daha yüksek bulmuştur. Naktiyok ve Timuroğlu'nun (2009) yaptığ çalışmada erkek öğrencilerin kız öğrencilere oranla daha fazla girişimcilik yapma niyeti olduğu sonucuna ulaşılmıştır.

Wilson ve diğerleri (2007) yaptıkları çalışmada girişimcilik eğitimi alan kız öğrencilerin girişimci öz-yetkinlik değerlerinin erkek öğrencilerden daha yüksek olduğu sonucu ortaya çıkmıştır. Mueller ve diğerleri'nin (2008) yaptığ kadınlar arasında girişimsel öz yeterlilik açısından anlamlı bir farklılık bulamamıştır. Kayalar ve Ömürbek'in (2007) Türkiye'de üniversite öğrencileri üzerine yaptığ 1 araştırmada ise, $\mathrm{k}_{1 \mathrm{z}}$ ve erkek öğrencilerin risk alma davranışları arasında bir fark bulunamamıştır. Yapılan çalışmalarda cinsiyete göre farklı bulguların elde edilmesi, çalışmalarda farklı ölçüm araçlarının kullanılması, ülkeden ülkeye değișen kültürel faktörler gibi nedenlerle açıklanabilir.

Eysenck kişilik anketi boyutları ve girişimci öz yeterlilik ölçeği boyutları arasındaki korelasyona bakıldığında dışa dönüklük boyutunun; yeni ürün ve pazar fırsatları geliştirmek, yenilikçi bir çevre oluşturmak, yatırımcılarla ilişkileri başlatmak, temel amacı tanımlamak, beklenmedik zorluklarla baş etmek boyutları arasında pozitif yönlü ve anlamlı bir ilişki ortaya çıkmıştır. Nörotizm boyutu ile yenilikçi bir çevre oluştur- mak ve yatırımcılarla ilişkileri başlatmak boyutları arasında ise negatif yönlü anlamlı bir ilişki bulunmuştur. Nörotizm ve diğer girişimci öz yeterlilik boyutları arasında ise anlamlı bir ilişki tespit edilememiştir. Son olarak, kişilik boyutlarından psikotizm ile girişimci öz yeterlilik boyutları arasında anlamlı bir ilişki bulunamamıştır.

Kişilik ve girişimcilik ile ilgili daha önce yapılan çalışmalara baktığımızda ise, farklı bulgular dikkati çekmektedir. Zhang ve diğ. (2009) çalışmasında, dışa dönük kişilik tipinin ve nörotik kişilik tipinin girişimcilik üzerine aracı (medyatör) etkisi olduğunu, ancak bu etkinin yalnızca kadın girişimciler için sağlandığını tespit etmiş̧tir. Erkek girişimciler için ileri sürülen aracı etki, her iki kişilik tipi için de kabul edilememiştir. Antoncic' in (2009) yaptığı bir araştırma dışadönük kişilik yapısı ile yeni sermaye yaratma arasinda pozitif, nörotik kişilik ile yeni sermaye yaratma arasında ise negatif bir ilişki olduğu tespit edilmiştir. Aynı çalışmada ki bir başka bulgu ise, dişa dönüklük ile teknolojik gelişmeye ayak uydurma arasında ilişkinin olmadığ 1 ancak nörotik kişilik ile teknolojik gelişmeye ayak uydurma arasında negatif bir ilişkinin olduğudur. Johnston ve di ğ. (2010) tarafından bilgi ve iletişim teknolojileri sektöründe girişimci olarak çalışmak isteyen öğrencilerin kişilikleri ve girişimcilik becerileri arasındaki ilişkileri araştırdıkları çalışmalarında, dışadönüklük ile girişimcilik arasında bir bağ ileri sürülmüştür. Bu çalışmalardan da görüldüğü gibi, girişimciliği ölçümde farklı araçların kullanılması ya da ele alınan kişilik boyutlarının farklılığ 1 gibi nedenlerden dolayı çalışmalarda farklı bulguların elde edildiği görülmektedir.

Bu bulguların ışığında girişimcilik özyeterliğini etkileyen en önemli kişilik özelliğinin dişadönüklük olduğu söylenebilir. Girişimciliğin doğası gereği, çevreyle sürekli etkileşimi gerekli kılması, yenilikçi ve risk almaktan korkmayan kişiler olması, dışadönük kişilik özelliği ile girişimciliği birbirine uyumlu k1lmaktadır. 


\section{Sonuç}

Girişimcilerin sahip olmuş oldukları kişilik özellikleri, başarılı olmaları için ekonomik ve sosyal faktörler kadar önemlidir. Kişilik özelliklerinin girişimci öz yeterlilik ile ilişkisini incelemek amacıyla yapılan bu çalışmadan elde edilen sonuçlara göre, dişa dönüklük boyutunun; yeni ürün ve pazar fırsatları geliştirmek, yenilikçi bir çevre oluşturmak, yatırımcılarla ilişkileri başlatmak, temel amacı tanımlamak, beklenmedik zorluklarla baş etmek boyutları arasında pozitif yönlü ve anlamlı bir ilişki ortaya çıkmıştır. Bu sonuç, dişa dönüklük boyutunun sosyalliği temsil ettiğini ve dolayısıyla insanlarla iletişimi seven, girişken ve ortak organize olmayı tercih eden bireylerde girişimciliğin ön plana çıktığını açıklamaktadır. Bu açıdan dişadönüklüğün girişimciliği etkileyen en önemli kişilik özelliği olduğu söylenebilir.

Girişimci öz yeterlikleri bağlamında kız ve erkek öğrencilerin genel olarak yetkinliklerinin birbirinden farklı olmadiğ 1 görülmektedir. $\mathrm{Bu}$ nedenle potansiyel olarak girişimci olma niyeti taşıyan öğrencilerin cinsiyet ayrımı olmaksızın desteklenmesi sonucuna ulaşılmaktadır. Çalışmada yapılan regresyon analizi sonucunda elde edilen önemli bir bulgu da, girişimci öz yeterlikleri bakımından en önemli kişilik tipinin, dışadönük kişilik tipi olmasıdır.

Bu çalışma farklı kişilik faktörleri (dışadönüklük, nörotisizm, psikotisizm) ile girişimciliği oluşturan temel değerlere (yeni ürün ve pazar fırsatları geliştirmek, yenilikçi bir çevre oluşturmak, yatırımcılarla ilişkileri başlatmak, temel amacı tanımlamak, beklenmedik zorluklarla baş etmek, temel insan kaynaklarını geliştirmek) ilişkin incelemelerde bulunması bakımından literatürdeki diğer çalışmalardan ayrılmaktadır. Çalışmada kullanılan ölçeklerin ilk defa bu amaçla bir araya gelmesi de çalışmanın bir diğer farklı yanını ortaya koymaktadır.

Çalışma bir başlangıç niteliği taşıdığından yalnızca öğrenciler ile yapılan araştırma sonuçlarını içermektedir. Bundan sonra yapılacak araștırmaların, hem girișimcileri hem de öğrencileri kapsayacak nitelikte olması, gerçek girişimciler ile girișimci olma niyeti taşıyan öğrencilerin kişilik değerlerinin bir arada görülmesine imkân sağlayacaktır. Ayrıca, yalnızca İktisadi ve İdari Bilimler Fakültesi öğrencilerini kapsayan bu çalışmanın, üniversitelerin farklı fakültelerinde eğitim gören öğrenciler üzerinde de gerçekleştirilmesi, fakülteler arası farklılıkları da ortaya koyacaktır. 


\section{Kaynakça}

Antoncic, B. (2009). The Entrepreneur's General Personality Traits and Technological Developments. World Academy of Science, Engineering and Technology, 53, 236-241.

Avşar, M. (2010). Yüksek Öğretimde Öğrencilerin Girişimcilik Eğilimlerinin Araştırılması, Çukurova Üniversitesinde Bir Uygulama. Çukurova Üniversitesi Sosyal Bilimler Enstitüsü. Yayınlanmamış Yüksek Lisans Tezi, Adana.

Aytaç, Ö. ve İlhan, S. (2007). Girişimcilik ve Girişimci Kültür: Sosyolojik Bir Perspektif. Selçuk Üniversitesi Sosyal Bilimler Enstitüsü Dergisi, 18, 101-120.

Baum, J.R., Frese, M., Baron, R.A. ve Katz, J.A. (2007). Entrepreneurship As an Area of Psychology Study: An Introduction, The Psychology of Entrepreneursip. Ed. J. Robert Baum, Michael Frese, Robert Baron, ss. 1-18, Lawrence Erlbaum Associates, New Jersey.

Bennis, W.G. ve Thomas, R.J. (2005). Liderlik Potaları, Harward Business Review Lider Geliştirme, (Çev. Barış Özçorlu), Mess Yayınlar, No:456, İstanbul.

Brindley, C. (2005). Barriers to Women Achieving Their Entrepreneurial Potential: Women and Risk. International Journal of Entrepreneurial Behaviour \& Research, 11(2), 144-161.

Bymes, J.P. ve Miller, D.C. (1999). Gender Differences in Risk Taking: A Meta Analysis. Psychological Bulletin, 125(3), 367-383.

Cansız, E. (2007). Üniversite Öğrencilerinin Girişimcilik Özelliklerinin Belirlenmesi: Süleyman Demirel Üniversitesi Öğrencileri Üzerine Bir Çalışma. Süleyman Demirel Üniversitesi Sosyal Bilimler Enstitüsü (Yayınlanmamıș Yüksek Lisans Tezi), Isparta.
Carsrud, A.L. ve Brannback, M.E. (2007). Entrepreneurship. Green Wood Press, USA.

Chen, C.C., Greene, P.G. ve Crick A. (1998). Does Entrepreneurial Self-Efficacy Distinguish Entrepreneurs from Managers?. Journal of Business Venturing, 13, 295-316.

De Noble, A.F., Jung, D. ve Ehrlich, S.B. (1999). Entrepreneurial Self-Eefficacy: The Development of a Measure and Its Relationship to Entrepreneurial Action, Frontiers for Entrepreneurship Research. http://www.babson.edu/entrep/fer/papers99/I/I_C/IC.html. (Erişim Tarihi: 10.03.2011).

Drucker, P.F. (2007). Innovation and Entrepreneurship. Butterworth - Heinemann Publications, UK.

Eysenck, H.J. ve Eysenck, S.B. (1975). Manual of the Eysenck Personality Questionnaire (Adult and Junior). Hodder \& Stoughton, London.

Eysenck, S.B.G., Eysenck, H.J. ve Barrett, P. (1985). A Revised Version of the Psychoticism Scale. Personal Individual Diffrences, 6, 21-29.

Francis, L.J., Brown, L.B ve Philipchalk, R. (1992). The development of an Abbreviated Form of the Revised Eysenck Personality Questionnaire (EPQR-A): Its Use Among Students in England, Canada, the USA and Australia. Personal Individual Diffrences, 13, 443-449.

İlter, B. (2008). Girişimcilik Sürecinde Kadın Girişimcilerin Karşılaştıkları Sorunların Analizi: Kagider Örneği. Afyon Kocatepe Üniversitesi Sosyal Bilimler Enstitüsü, Yayınlanmamış Doktora Tezi, Afyonkarahisar. 
Johnston, K.A, Andersen, B.K., Pitts, J.D. Saunders, M.O. (2010). Identifying ICT Entrepreneurship Potential in Students. Proceedings of Informing Science and IT Education Conference. pp. 27-41. http:/ / proceedings.informingscience.org/InSITE2010/InSITE10p027041Johnston704.pdf. (Erişim Tarihi: 10.03.2011)

Karanc1, N., Dirik, G. ve Yorulmaz, O. (2007). Reliability and Validity Studies of Turkish Translation of Eysenck Personality Questionnaire Revised-Abbreviated. Turkish Journal of Psychiatry, 18(3), 17.

Kayalar, M. ve Ömürbek, N. (2007). Girişimci Adaylarının Risk Almaya Yatkınlık Özelliğinin Cinsiyet Bağlamında İncelenmesi. Atatürk Üniversitesi İ̈BF Dergisi, 21(1), 185-200.

Kickul, W.F. ve D'Intino, J.M. (2007). Gender, entrepreneurial self-efficacy, and entrepreneurial career intentions: Implications for entrepreneurship education. Entrepreneurship Theory \& Practice, 31(3), 387-406.

Krueger, N.F. (2000). The Cognitive Infrastructure of Opportunity Emergence. Entrepreneurship: Theory \& Practice, 24(3), 5-23.

Kutanis, R.Ö. ve Alpaslan, S. (2007). Bir Doğu Liderliğinin Metaforik Analizi: Konusoke Matsushita, 15. Yönetim ve Organizasyon Kongresi Bildiriler Kitabı, 25-27 Mayıs, Sakarya, 25-33.

Lee, S.Y., Florida, R. ve Acs, Z.J. (2004). Creativity and Entrepreneurship: A Regional Analysis of New Firm Formation. Regional Studies, 38(8), 879-891.

Morrison, A. (2000). Entrepreneurship: What Triggers It? International Journal of Enrepreneurial Behaviour and Research, 6(2), 59-71.
Mueller S.L. ve Danton, M.C. (2007). Gender-Role Orientation As A Determinant Of Entrepreneurial Self-Efficacy. Journal of Developmental Entrepreneurship, 13(1), 3-20.

Naktiyok, A. ve Timuroğlu, M.K. (2009). Öğrencilerin Motivasyonel Değerlerinin Girişimcilik Niyeti Üzerine Etkisi ve Bir Uygulama. Atatürk Üniversitesi İİBF Dergisi, 23(3), 85-103.

Naktiyok, A., Karabey, Canan, N. ve Güllüce, A.Ç. (2010). Entrepreneurial SelfEfficacy and Entrepreneurial Intention: The Turkish Case. International Entrepreneurship and Management Journal, 6(4), 419-435.

Odabaşı, Y. (2005). Girişimcilik. T.C. Anadolu Üniversitesi Yayını No:1567, Eskişehir

OECD, (2005). Türkiye'deki Dinamik Küçük ve Orta Ölçekli İşletmelerin Geliştirilmesine ve Finansmanına Yönelik Çerçeve. OECD Publication, İstanbul.

Oosterbeek, H., van Praag, M. ve Ljsselstein, A. (2010). The Impact of Entrepreneurship Education on Entrepreneurship Skills and Motivations. European Economic Review, 54(3), 442-454.

Özden, K., Timurlenk, M.S. ve Başar, S. (2008). Girişimcilik Eğilimi: KırgızistanTürkiye Manas Üniversitesi ve Atatürk Üniversitesi Öğrencileri üzerine bir Araştırma. 2. Uluslararası Girişimcilik Kongresi Bildiri Kitabı, Kırgızistan-Türkiye Manas Üniversitesi Yayınları: 112, Kongreler Dizisi: 16, 229-240.

Roberts, E.B. (1991). Entrepreneurs in High Technology: Lessons from MIT and Beyond Oxford University Press. New York.

Sabuncuoğlu, Z. ve Tokol, T. (2009). İşletme. Furkan Ofset, Bursa. 
Schmiemann, M. (2008). Enterprises by Size Class - Overview of SMEs in the EU. Eurostat Publication, Luxembourg. Erişim Adresi: http://epp.eurostat.ec.europa.eu/cache/ITY_OFFPUB/KS-SF-0 8-031/EN/KS-SF-08-031-EN.PDF (Erişim Tarihi: 10.02.2011)

Shane, S. (2003). A General theory of entrepreneurship. Edward Elgar Publishing. UK.

Shane, S. (2010). Born Entrepreneurs, Born Leaders: How Your Genes Affect Your Work Life. Oxford University Press, New York.

Sondakh, D.F. ve Rajah, K.K. (2006). Developing an Entrepreneurship Culture, The Greenwich Experience. Entrepreneurship and Innovation, 7(4), 231-241.

Taylor, S.R. ve Newcomer, J.D. (2005). Characteristics of Woman Small Business Owners. International Handbook of Woman and Small Business Entrepreneurship, Ed. Sandra L. Fierdman, Marilyn J. Davidson, Edward Eldar Publishing, UK.

Tiryaki, A. (2005). Theories of Entrepreneurship: A Critical Overview. Dumlup1nar Üniversitesi Sosyal Bilimler Dergisi, $13,31-42$.

TÜSİAD (2002). Türkiye'de Girişimcilik. Yayın No. TÜSİAD-T/2002-12/340, İstanbul.

Wilson, F., Kickul, J. ve Marlino, D. (2007). Gender, entrepreneurial self-efficacy, and entrepreneurial career intentions: Implications for entrepreneurship education. Entrepreneurship Theory and Practice, 31(3), 387-401.

Wooten, K., T. Timmerman ve R. Folger. (1999). The use of personality and the five factor model to predict new bussiness ventures: From outplacement tostart up. Journal of Vocational Behavior, 54(1), 82-101.
Zhang, Z., Zyphur, M.J., Narayanan, J., Arvey, R.D., Chaturvedi, S., Avolio, B.J., Lichtenstein, P., ve Larsson, G. (2009). The genetic basis of entrepreneurship: Effects of gender and personality. Organizational Behavior and Human Decision Processes, 110, 93-107. 